\title{
Digestion of non-starch polysaccharides by non-ruminant omnivores
}

\author{
BY J. C. MATHERS \\ Department of Agricultural Biochemistry and Nutrition, University of Newcastle upon Tyne, \\ Newcastle upon Tyne NE1 7RU
}

The definition of fibre, particularly in the context of foods eaten by man, is still controversial. For the purposes of the present paper, a reductionist view will be taken and fibre considered to be non-starch polysaccharides (NSP), since in making digestibility measurements a definition is required which can be translated into an analytical method suitable for use with foods and faeces. This reductionist approach ignores many other food components including starches resistant to pancreatic amylase, oligosaccharides, lactose (for most animals and man post weaning), some protein and lipid fractions (Cummings \& Englyst, 1987) and organic anions such as oxalate and tartrate (Florin et al. 1990) which, in the large intestine (LI), behave similarly to some NSP and might be included within the definition of fibre by those taking an holistic view. However, there is little quantitative information on the amounts of these fractions in foods or their sites and extents of digestion so that the restricted definition of fibre is justified at present.

\section{SITES OF DIGESTION}

Over the past 10 years, several studies have examined the digestion of NSP anterior to the caecum in pigs fitted with cannulas in the terminal ileum or by slaughter and in man using ileostomists (Fig. 1). In pigs, a considerable proportion (up to two-thirds) of the

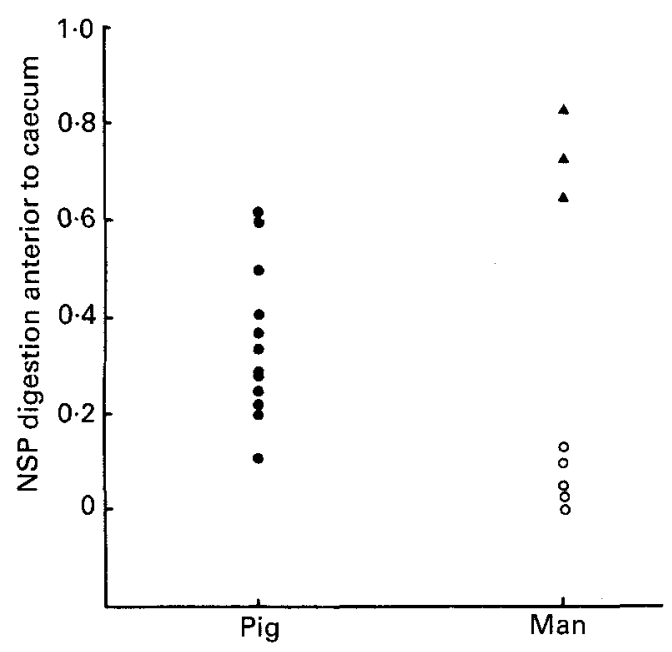

Fig. 1. Digestion of non-starch polysaccharides (NSP) anterior to the caecum in the pig (O) and in man (O), A). Values for pigs are from Millard \& Chesson (1984), Graham et al. (1986), Fadel et al. (1988, 1989), Goodlad (1989) and Longland et al. (1989) and for man from Sandberg et al. (1981, 1986), Englyst \& Cummings $(1985,1986,1987)$ and, for hemicellulose only ( $\boldsymbol{\Delta})$, from Holloway et al. $(1978,1980)$. 
NSP ingested disappeared in the upper intestine whilst relatively little did so in man. This marked between-species difference is probably due to the much longer small intestine and relatively high ileal bacterial density in the pig (Chesson et al. 1985; Liu et al. 1985). Early reports of substantial precaecal disappearance of hemicellulose in man (Holloway et al. 1978, 1980) appear anomalous and many have resulted from the use of less-reliable analytical methods.

When uncooked peas (Pisum sativum) were fed to growing pigs, approximately 0.4 of total NSP but no cellulose disappeared in the upper intestine so that it was the non-cellulosic polysaccharides (NCP) which were most extensively digested before the caecum (Goodlad, 1989). Similar results were reported by Fadel et al. (1989) for uncooked barley-based diets eaten by pigs. Virtually all the $\beta$-glucans, approximately 0.4 of the NCP pentose sugars, xylose and arabinose, but no cellulose was digested before the terminal ileum. In this respect, the pig appears to be a poor model for man but if the NSP disappearing in the pig upper intestine does so by fermentation to volatile fatty acid (VFA) as occurs in the human LI, then the metabolic and nutritional consequences may be similar. The chicken also differs from man in that $0.3-0.4$ of ingested cereal NSP was digested before the caecum possibly in the crop and gizzard (Petterson \& Åman, 1989).

\section{FACTORS AFFECTING EXTENT OF NSP DIGESTION}

1. Cooking. Goodlad (1989) compared the digestibility in the rat of NSP and its monomeric constituents from raw and cooked peas (Fig. 2). Although there were some statistically significant effects of cooking, e.g. higher digestibility for NCP and its arabinose and uronic acids fractions, in general the differences due to cooking were small and biologically unimportant. Of more nutritional significance is the extent of NSP digestion ( 0.6 overall and almost 1.0 for arabinose) indicating that fibre digestion is extensive even in the rat. Fadel et al. $(1988,1989)$ also reported very small increases in digestibility by pigs of NSP and some monosaccharide constituents when barley-based diets were extrusion cooked or baked, with the xylose-containing polymers having the lowest digestibility $(0 \cdot 42-0.66)$ and the $\beta$-glucans being totally digested for both raw and cooked diets.

Whilst these limited results suggest that cooking has no major effects on the overall extent of NSP digestion, it may have more subtle effects on, for example, the rate of NSP digestion or the amounts of other food components, notably starch (Englyst \& Kingman, 1990) which reach the LI. Such effects could be important physiologically and deserve investigation.

2. Age and body-weight. It is sometimes supposed that older or larger animals are able to digest NSP more extensively than younger or smaller animals, but there is little experimental evidence in this area. One useful study is that by Longland \& Low (1989) who measured the digestibility of NSP by pigs when they were $27 \mathrm{~kg}$ and again when they were $50 \mathrm{~kg}$ live weight. At both live weights, a range of diets varying in NSP concentration over an almost twofold range, obtained by varying the sugar-beet pulp content, were tested. For the younger (lighter) pigs, sugar-beet pulp (plain or molassed) inclusion rates up to $300 \mathrm{~g} / \mathrm{kg}$ led to increases in NSP digestibility, possibly because the sugar-beet pulp was more digestible than the other dietary components (mostly cereal) which it replaced. With the highest sugar-beet pulp inclusion rate $(450 \mathrm{~g} / \mathrm{kg})$, there was no change (molassed) or a marked fall (plain) in NSP digestibility, possibly indicating 


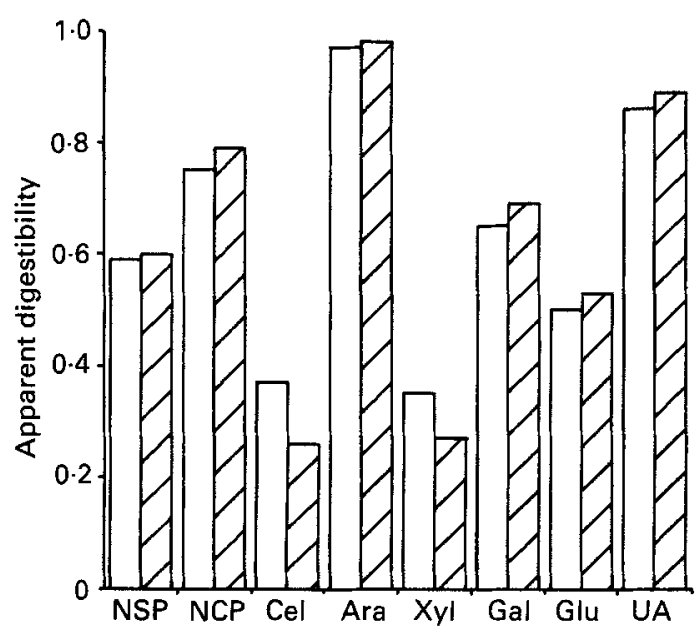

Fig. 2. Digestibility in the rat of non-starch polysaccharides (NSP) and constituents from raw ( $\square$ ) and cooked (שT) peas (Pisum sativum). NCP, non-cellulosic polysacchatides; Cel, cellulose; Ara, arabinose; Xyl, xylose; Gal, galactose; Glu, glucose, UA, uronic acids. (Values from Goodlad, 1989.)

that the capacity for digestion was being reached. When the pigs were re-tested at $50 \mathrm{~kg}$ live weight, there was uniformly better NSP digestibility and a steady increase with increasing sugar-beet pulp inclusion rate and dietary NSP concentration. It is worth noting that over $0 \cdot 8$ of the dietary NSP were digested by the heavier pigs given the highest fibre diets.

However, it should not be concluded on the basis of this study that older (or heavier) animals digest NSP more effectively. In this particular series of experiments, both age and live weight were confounded with time of exposure to the diet so that an adaptation effect cannot be separated from a time effect due to increasing maturity.

3. Dietary NSP concentration. We have tested the capacity of rats and pigs to digest NSP from human foods when the dietary NSP concentration varied widely. For example, Key (1990) offered rats diets based on freeze-dried white or wholemeal bread $(500 \mathrm{~g} / \mathrm{kg})$ which included graded amounts (up to $450 \mathrm{~g} / \mathrm{kg}$ ) of cooked and freeze-dried haricot beans (Phaseolus vulgaris) (Fig. 3). Where white bread formed the basal diet ingredient, there was a sevenfold range of NSP intake whilst with wholemeal bread, the starting NSP intake was higher and intake varied over a fourfold range. For both experiments, there were strong linear relationships between NSP intake and output providing convincing evidence that, in these circumstances, the rat is able to respond to each increment in NSP intake by equally effective NSP digestion. The slopes of the lines could be used as measures of the indigestibility of haricot beans NSP. However, Key \& Mathers (1990) and Goodlad \& Mathers (1991) describe a multiple linear regression technique which can be used to calculate individual digestibilities for each component when two (or more) foods are eaten in mixed diets. Using the latter approach, we calculated digestibilities of 0.82 and 0.56 for white and wholemeal breads respectively and 0.82 and 0.86 for the haricot beans used in the two experiments. Similarly, when wheat $(500 \mathrm{~g} / \mathrm{kg}$ diet $)$ and raw peas $(0-300 \mathrm{~g} / \mathrm{kg}$ diet $)$ were fed in mixed diets to pigs, there were strong linear relationships between NSP intake and faecal NSP output with digestibilities of 0.65 and 0.85 for wheat and peas NSP respectively (Goodlad \& Mathers, 1991). 




Fig. 3. Relationships between non-starch polysaccharide (NSP) intake and faecal NSP output in rats fed on (a) white bread- and (b) wholemeal bread-based diets containing graded amounts of cooked, freeze-dried and ground haricot beans (Phaseolus vulgaris). In each case the freeze-dried, ground bread provided $500 \mathrm{~g} / \mathrm{kg} \mathrm{diet}$ and the haricot beans $0-450 \mathrm{~g} / \mathrm{kg}$ diet. (Values from Key (1990).)

4. Transit time. Many studies of plant cell wall fermentation have established that this is a relatively slow process (Van Soest et al. 1983; Van Soest, 1984) so it would be reasonable to assume that alterations in LI transit time (TT) might influence the extent of NSP digestion in that organ. To test this hypothesis, Stephen et al. (1987) deliberately altered whole-gut TT in human volunteers by pharmacological means using Senokot to reduce TT (from 64 to $35 \mathrm{~h}$ ) and codeine alone, or with loperamide, to increase TT (from 47 to $88 \mathrm{~h}$ ); NSP intake remained unaltered (Fig. 4). Reducing TT had little effect on faecal output of the major pentose sugars, xylose and arabinose, but increased output of cellulose, markedly so for those taking Senokot. Since cellulose is often the NSP fraction with the lowest digestibility, alterations in the time available for microbial degradation are more likely to influence this fraction than the more-readily fermentable arabinoseand xylose-containing polymers. 




Fig. 4. Relationships between whole-gut transit time (TT) and faecal output of major NSP constituents in man. In these studies NSP intake remained constant whilst TT was altered by pharmacological means (Stephen et al. 1987).

\section{USE OF THE RAT AS A MODEL FOR MAN}

Whilst several important studies of NSP digestion in man have been carried out (for review of earlier work, see Cummings, 1981), such experiments require considerable co-operation from the subjects over a prolonged period of time and it is not easy to obtain digestibility estimates for individual foods. As an alternative, the rat has been used as a model for man but the experimental justification for this approach is limited. In a joint study by Nyman et al. (1986), the digestibilities of concentrated sources of NSP, which had been tested previously in human volunteers, were determined in the rat. The range of digestibilities was considerable from approximately 0.4 (wheat bran) to almost 1.0 (guar gum) but across the whole range values for both species were similar. However, since the analytical methods used for NSP determination were not identical for the two parts of the study, some caution should be exercised in drawing definitive conclusions.

More recently, a Danish-German collaboration has further tested the usefulness of the rat as a model for man. Two contrasting diets, one low $(18.8 \mathrm{~g} / \mathrm{d})$ and the other high $(52 \mathrm{~g} / \mathrm{d})$ in NSP, were eaten by human volunteers (E. Wisker and W. Feldheim, unpublished results) and composite samples of each of the diets were also fed to rats (I. Hansen, R. B. Knudsen and B. O. Eggum, unpublished results). The same analytical methods were used in both parts of the study. For both diets, digestibility of NSP and its monosaccharide components was consistently higher for man than for rats (Fig. 5). This between-species difference was apparently greater for the higher-NSP diet and especially for the less-well-digested fractions, the xylans and glucans (the latter probably being mainly cellulose). The lower digestibility by rats may relate to the more limited time 


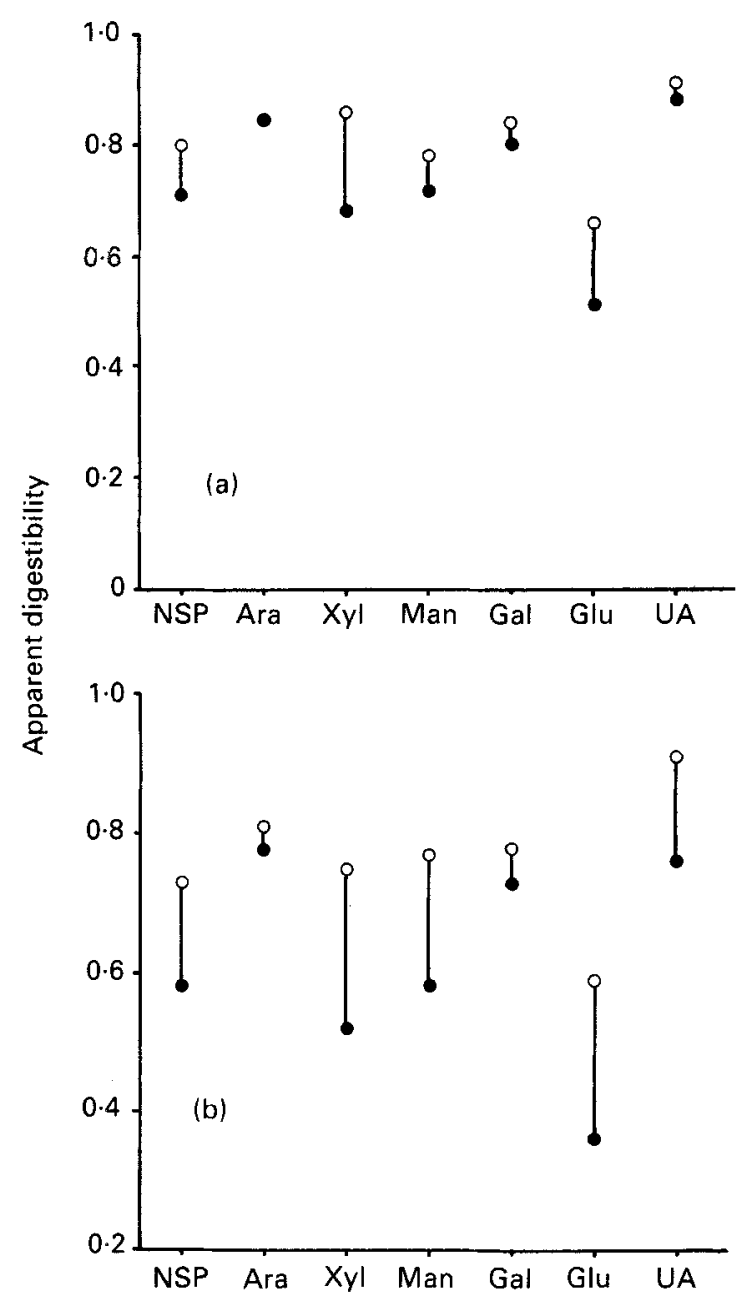

Fig. 5. Digestibilities of non-starch polysaccharides (NSP) and constituents in man (O) and in the rat (O) each fed on the same (a) low-fibre and (b) high-fibre diets. In man, the low-and high-fibre diets provided 18.8 and 52 g NSP/d respectively. Ara, arabinose; Xyl, xylose; Man, mannose; Gal, galactose; Glu, glucose; UA, uronic acids. Unpublished results from E. Wisker and W. Feldheim (man) and I. Hansen, R. B. Knudsen and B. O. Eggum (rat).

available for fermentation in the rat caecum ( $8-10 \mathrm{~h}$ for animals fed on high-NSP diets; Goodlad \& Mathers, 1990; Mathers et al. 1990) than in the right and transverse colon of man (14-26 h; Metcalf et al. 1987). Clearly further critical comparisons are needed of NSP digestibility by rat and man before it can be assumed that results from one species will always apply to the other.

\section{OTHER BETWEEN-SPECIES COMPARISONS}

There is very little information on NSP digestion for the same or closely similar foods by different species but values are available for raw peas fed to cockerels (Longstaff \& McNab, 1987), rats (Goodlad \& Mathers, 1990) and pigs (Goodlad \& Mathers, 1991). 


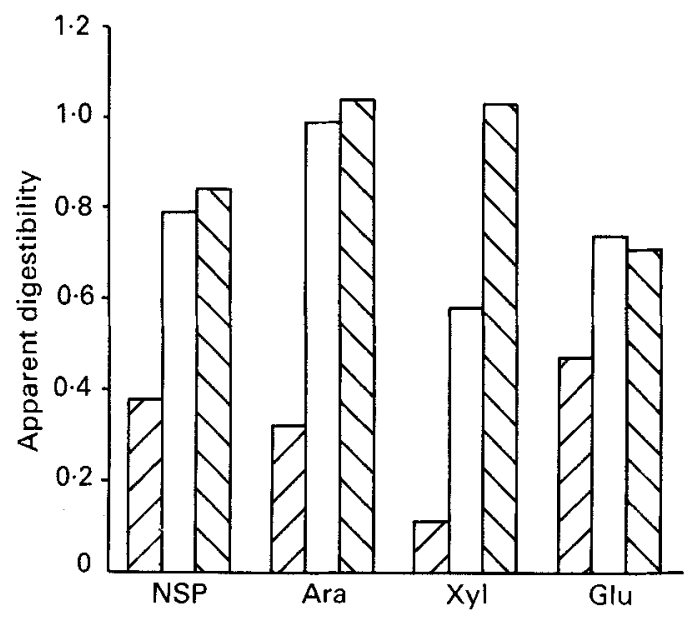

Fig. 6. Comparative digestibilities of non-starch polysaccharides (NSP) and major constituent monosaccharides of raw peas (Pisum sativum) by cockerels (囚, Longstaff \& McNab, 1987), rats ( $\square$, Goodlad \& Mathers, 1990) and pigs ( Goodlad \& Mathers, 1991). Ara, arabinose; Xyl, xylose; Glu, glucose.

Consideration of Fig. 6 shows that the digestibility of NSP and each of its main constituent sugars, arabinose, xylose and glucose, was much lower for the chicken and higher and similar for rats and pigs, except for xylose where digestibility was 1.0 for the pig and only 0.6 for the rat. Part of the between-species difference may be due to difference in experimental protocol. In contrast to the rats and pigs which were offered the experimental diets for at least $7 \mathrm{~d}$ before faecal collections were started, the cockerels studied by Longstaff \& McNab (1987) were starved for $48 \mathrm{~h}$ before being tube-fed a single meal of peas. This starvation and lack of opportunity for adaptation to the test food may have adversely affected NSP digestion by the chickens. However, the major reason for the lower NSP digestion by poultry is probably the relatively short time that food residues are held within the gut and particularly in the caeca. Better understanding, and the potential for prediction, of the extent of NSP digestion by non-ruminant animals will require more knowledge of factors influencing the rate of polymer degradation and the time available for this process in the various gut compartments.

\section{ENERGY SALVAGE BY NSP FERMENTATION}

In calculating the energy gain from NSP digestion in the LI, the simple model shown in Fig. 7 will be used. NSP entering the LI are fermented to a greater or lesser degree with the production of VFA, gases, heat and bacterial cells but only the absorbed VFA make a significant contribution to energy salvage.

The major determinant of energy salvage is the amount of NSP fermented and it is assumed that this can be estimated as food-to-faeces disappearance. Since some of this organic matter $(\mathrm{OM})$ will be incorporated into bacterial cells, a means of predicting net bacterial cell yield per unit NSP fermented is required. Such information can be derived from the Cambridge study (Cummings, 1984) in which human volunteers were given NSP supplements in the form of cabbage, carrot and wheat bran, NSP digestibility was measured and the additional bacterial DM output in faeces was determined gravi- 




Fig. 7. Conceptual model of large bowel fermentation used in calculation of energy salvage from non-starch polysaccharides digestion.

metrically (Stephen \& Cummings, 1980). Although there was variability in yield between supplements, the estimates were reasonably close and the overall mean ( $300 \mathrm{mg}$ bacterial dry matter (DM)/g NSP fermented) is similar to values for bacterial yield in the rumen (Mathers \& Miller, 1981; Agricultural Research Council, 1984). Since each gram of bacterial DM contains about $0.875 \mathrm{~g} \mathrm{OM}$, bacterial OM yield is approximately $263 \mathrm{mg} / \mathrm{g}$ fermented NSP.

The pattern of VFA found in the LI is readily altered by diet (Cheng et al. 1987; Key \& Mathers, 1987; Goodlad \& Mathers, 1990; Mathers et al. 1990), but from the viewpoint of energy salvage it is the proportion of propionate which is most important. For this calculation, two fermentation patterns will be used: type I with molar proportions (mmol/mol) of 650, 200 and 150 for acetate, propionate and butyrate respectively and type II where propionate contributes $350 \mathrm{mmol} / \mathrm{mol}$ at the expense of acetate (Table 1). Finally, it is assumed that NSP fermentation follows conventional anaerobic stoichiometry, i.e. each hexose molecule can give rise to two molecules of acetate or two molecules of propionate or one molecule of butyrate and that 0.95 of net VFA production is absorbed. On these assumptions, net VFA production and energy salvage (using heats of combustion of cellulose and of individual VFA; Blaxter, 1989) per g NSP fermented were estimated (Table 1). As expected, energy absorbed as propionate is considerably greater for type II than for type I fermentation pattern and, overall energy absorption increases from 9.0 to $9.8 \mathrm{~kJ} / \mathrm{g}$ fermented NSP.

The stoichiometry used previously may not always be appropriate for the large bowel since work with LI contents from rodents (Prins \& Lankhorst, 1977), pigs (De Graeve et al. 1990) and man (Lajoie et al. 1988; Gibson et al. 1990) has shown that acetogenesis, i.e. the synthesis of acetate from carbon dioxide and hydrogen may occur in some circumstances. The extent of acetogenesis in vivo has not been quantified, but using the stoichiometry suggested by Wolin \& Miller (1983) it may be calculated that in the 
Table 1. Estimates of volatile fatty acid (VFA) absorption (mol) and energy salvage (MJ) per kg non-starch polysaccharides (NSP) fermented in the large bowel, for two contrasting fermentation patterns one 'typical' pattern (type I) and another high in propionate (type II)

\begin{tabular}{|c|c|c|c|c|c|c|}
\hline \multirow[t]{2}{*}{ VFA pattern ... } & \multicolumn{3}{|c|}{ Type I } & \multicolumn{3}{|c|}{ Type II } \\
\hline & $\begin{array}{c}\text { VFA } \\
\text { pattern } \\
(\mathrm{mmol} / \mathrm{mol})\end{array}$ & $\begin{array}{c}\text { VFA } \\
\text { absorption } \\
\text { (mol) }\end{array}$ & $\begin{array}{c}\text { Energy } \\
\text { salvage } \\
\text { (MJ) }\end{array}$ & $\begin{array}{c}\text { VFA } \\
\text { pattern } \\
(\mathrm{mmol} / \mathrm{mol})\end{array}$ & $\begin{array}{c}\text { VFA } \\
\text { absorption } \\
\text { (mol) }\end{array}$ & $\begin{array}{c}\text { Energy } \\
\text { salvage } \\
(\mathrm{MJ})\end{array}$ \\
\hline Acetate & 650 & $4 \cdot 88$ & $4 \cdot 27$ & 500 & 3.76 & 3.29 \\
\hline Propionate & 200 & 1.50 & $2 \cdot 29$ & 350 & 2.63 & 4.02 \\
\hline Butyrate & 150 & $1 \cdot 13$ & $2 \cdot 47$ & 150 & $1 \cdot 13$ & $2 \cdot 47$ \\
\hline Total & & & 9.03 & & & $9 \cdot 78$ \\
\hline \multicolumn{7}{|l|}{ Proportion of } \\
\hline NSP energy* & & & 0.52 & & & 0.56 \\
\hline
\end{tabular}

* Assuming fermented NSP was cellulose and using heats of combustion of cellulose and of VFA given by Blaxter (1989).

presence of acetogenesis, energy capture in VFA may be $15 \%$ greater than in its absence.

Whilst experimental support for some of the assumptions used in this model building is limited and requires further research, the principles used are sound and it is concluded that LI fermentation of NSP will result in substantial energy salvage of approximately $0.5-0.6$ of the gross energy in the fermented NSP.

\section{TRANSGENIC ANIMALS}

Procedures are being developed which will allow the insertion into the mammalian or avian genome of heterologous genes derived from bacterial or fungal sources. The use of these emerging technologies in molecular biology offers the potential for genetic manipulation of non-ruminant omnivores to create transgenic animals which secrete NSP-degrading enzymes. Some of the approaches used and progress being made in this area are described by Gilbert \& Hazlewood (1991). The objective here is to highlight some of the strategic considerations which should be addressed in undertaking such work.

1. Target polymers. Genes have been isolated which encode enzymes for the degradation of cellulose and some of the NCP including $\beta$-glucans, xylans and pectic substances. Clearly if cellulose is the target polymer, and hydrolysis is complete, the resulting sugar, glucose, will be readily absorbed and no nutritional problems would be anticipated. However, the NCP are a very heterogenous group containing different proportions of various monosaccharides each of which has different fates in the intestine (Table 2). If NCP hydrolysis yields xylose, arabinose, rhamnose and uronic acids, these will largely flow to the LI and undergo extensive fermentation so that the advantage for the host animal would be minimal, and indeed there could be considerable disadvantage through the induction of osmotic diarrhoea (Longstaff et al. 1988). Thus, the expression of polysaccharidases which release the major hexoses, glucose and galactose, could be energetically advantageous but the nutritional benefit in releasing other NSP monosaccharides within the small intestine is doubtful. 
Table 2. Monosaccharide products of hydrolysis of non-cellulosic polysaccharides and their metabolic fates

\begin{tabular}{|c|c|}
\hline Monosaccharide & Metabolic fate \\
\hline $\begin{array}{l}\text { Glucose } \\
\text { Galactose }\end{array}$ & Well absorbed and efficiently metabolized \\
\hline Xylose & Partially absorbed, partially metabolized \\
\hline $\begin{array}{l}\text { Arabinose } \\
\text { Rhamnose } \\
\text { Uronic acids }\end{array}$ & $\begin{array}{l}\text { Partly absorbed and extensively fermented in } \\
\text { the large bowel }\end{array}$ \\
\hline
\end{tabular}

2. Sites of expression. Such heterologous genes might be expressed at several sites in the gastrointestinal tract including the salivary glands and the stomach. In either of these sites, the foreign gene product could be linked to another protein, e.g. pepsinogen, already being secreted. For most species, food is retained in the stomach for a relatively long time so that if genes encoding polysaccharidases could be engineered so that their products were active at low $\mathrm{pH}$, this could be advantageous. Most of the polymersplitting enzymes secreted into the small intestine are derived from the pancreas so this organ would be another potential site of expression. The liver is another potential expression site with secretion into bile. I suspect that expression on the brush border would only be effective if the gene product was released into the gut lumen and not anchored on the microvilli as is the case for peptidases and oligosaccharidases.

3. Regulation of expression. We must first ask, is regulation of expression necessary? In other words, should the transgenic animal possess a mechanism which regulates the amount of the foreign enzyme which is secreted both over time and in response to variations in diet? If the answer is yes, as I suspect it will be, then there are two options. This regulation could be indirect, for example, linked to the expression and secretion of another gut enzyme such as pepsinogen or trypsinogen. Direct regulation which involved sensing the presence of the target polymer in the gut, conveying this information to the expression site and modulating the protein synthetic process from transcription, through translation and post-translation modification to secretion, would be a much bigger challenge and clearly beyond what is likely to be possible in the medium term.

4. Benefits and disadvantages. From the scientist's perspective, the greatest benefit from this type of transgenic animal research will be in increased understanding of cell biology and digestive physiology and biochemistry and is, in my view, the major justification for such work. Clearly, it can be argued that these technologies will bring economic advantages in, for example, better use of plant cell wall-rich foods by non-ruminant animals which may reduce the latter's dependence on starchy foods which can be consumed directly by man. In addition, the early hydrolysis of $\beta$-glucans and other soluble NSP could reduce the deleterious effects which these substances have in some young animals, in particular chicks.

Against these benefits must be weighed possible disadvantages which include considerations of animal welfare. I have indicated previously how choosing the wrong target polymer could induce osmotic diarrhoea and failure to regulate the expression of the heterologous gene could have other deleterious effects. The development of transgenic animals is an expensive undertaking and it could be argued that the resources committed 
in this endeavour could be better spent in the development of cheap and effective feed-processing methods or of enzymes for use as feed additives. Finally, there may be public resistance to the introduction into the human food chain of transgenic animals.

The author wishes to thank Dr Hansen and her colleagues for allowing him to refer to their unpublished comparisons of NSP digestibility in man and the rat.

\section{REFERENCES}

Agricultural Research Council (1984). The Nutrient Requirements of Ruminant Livestock, Suppl. no. 1. Slough: Commonwealth Agricultural Bureaux.

Blaxter, K. L. (1989). Energy Metabolism in Animals and Man. Cambridge: Cambridge University Press.

Cheng, B.-Q., Trimble, R. P., Illman, R. J., Stone, B. A. \& Topping, D. L. (1987). Comparative effects of dietary wheat bran and its morphological components (aleurone and pericarp-seed coat) on volatile fatty acid concentrations in the rat. British Journal of Nutrition 57, 69-76.

Chesson, A., Richardson, A. J. \& Robertson, J. A. (1985). Fibre digestion and bacteriology of the digestive tract of pigs fed cereal and vegetable fibre. In Digestive Physiology of the Pig, Report no. 580, pp. 272-275 [A. Just, H. Jorgensen and J. A. Fernandez, editors]. Copenhagen: National Institute of Animal Science.

Cummings, J. H. (1981). Dietary fibre. British Medical Bulletin 37, 65-70.

Cummings, J. H. (1984). Microbial digestion of complex carbohydrates in man. Proceedings of the Nutrition Society $43,35-44$.

Cummings, J. H. \& Englyst, H. N. (1987). Fermentation in the human large intestine and the available substrates. American Journal of Clinical Nutrition 45, 1243-1255.

De Graeve, K. G., Grivet, J. P., Durand, M., Beaumartin, P. \& Demeyer, D. (1990). NMR study of ${ }^{13} \mathrm{CO}_{2}$ incorporation into short-chain fatty acids by pig large-intestinal flora. Canadian Journal of Microbiology 36, 579-582.

Englyst, H. N. \& Cummings, J. H. (1985). Digestion of the polysaccharides of some cereal foods in the human small intestine. American Journal of Clinical Nutrition 42, 778-787.

Englyst, H. N. \& Cummings, J. H. (1986). Digestion of the carbohydrates of banana (Musa paradisiaca sapientum) in the human small intestine. American Journal of Clinical Nutrition 44, 42-50.

Englyst, H. N. \& Cummings, J. H. (1987). Digestion of the polysaccharides of potato in the small intestine of man. American Journal of Clinical Nutrition 45, 423-431.

Englyst, H. N. \& Kingman, S. M. (1990). Dietary fiber and resistant starch. A nutritional classification of plant polysaccharides. In Dietary Fiber, pp. 49-65 [D. Kristchevsky, C. Bonfield and J. W. Anderson, editors]. New York: Plenum Publishing Corporation.

Fadel, J. G., Newman, C. W., Newman, R. K. \& Graham, H. (1988). Effects of extrusion cooking of barley on ileal and fecal digestibility of dietary components in pigs. Canadian Journal of Animal Science 68, 891-897.

Fadel, J. G., Newman, R. K., Newman, C. W. \& Graham, H. (1989). Effects of baking hulless barley on the digestibility of dietary components as measured at the ileum and in the feces of pigs. Journal of Nutrition $119,722-726$.

Florin, T. H. J., Neale, G. \& Cummings, J. H. (1990). Dietary organic anions can make a significant contribution to the total fermentable material in the human large intestine. Proceedings of the Nutrition Society 50, 226A.

Gibson, G. R., Cummings, J. H., Macfarlane, G. T., Allison, C., Segal, I., Vorster, H. H. \& Walker, A. R. P. (1990). Alternative pathways for hydrogen disposal in the human colon. Gut 31, 679-683.

Gilbert, H. J. \& Hazlewood, G. P. (1991). Genetic modification of fibre digestion. Proceedings of the Nutrition Society 50, 173-184.

Goodlad, J. S. (1989). Digestion and large intestinal fermentation of pea (Pisum sativum) carbohydrates. $\mathrm{PhD}$ Thesis, University of Newcastle upon Tyne.

Goodlad, J. S. \& Mathers, J. C. (1990). Large bowel fermentation in rats given diets containing raw peas (Pisum sativum). British Journal of Nutrition 64, 569-587.

Goodlad, J. S. \& Mathers, J. C. (1991). Digestion by pigs of non-starch polysaccharides in wheat and raw peas (Pisum sativum) fed in mixed diets. British Journal of Nutrition 65, 259-270.

Graham, H., Hesselman, K. \& Åman, P. (1986). The influence of wheat bran and sugar-beet pulp on the digestibility of dietary components in a cereal-based pig diet. Journal of Nutrition 116, 242-251. 
Holloway, W. D., Tasman-Jones, C. \& Bell, E. (1980). The hemicellulose component of dietary fiber. American Journal of Clinical Nutrition 33, 260-263.

Holloway, W. D., Tasman-Jones, C. \& Lee, S. P. (1978). Digestion of certain fractions of dietary fiber in humans. American Journal of Clinical Nutrition 31, 927-930.

Key, F. B. (1990). Digestion and large intestinal fermentation of breads and haricot beans (Phaseolus vulgaris). PhD Thesis, University of Newcastle upon Tyne.

Key, F. B. \& Mathers, J. C. (1987). Response of caecal metabolism to varying proportions of white and wholemeal breads. In Dietary Fibre: Chemical and Biological Aspects, pp. 254-258 [D. A. T. Southgate, K. Waldron, I. T. Johnson and G. R. Fenwick, editors]. Cambridge: Royal Society of Chemistry.

Key, F. B. \& Mathers, J. C. (1990). Estimation of the digestibilities of NSP for wholemeal bread and haricot beans fed in mixed diets. Proceedings of FIBRE 90 Conference, Norwich.

Lajoie, S. F., Bank, S., Miller, T. L. \& Wolin, M. J. (1988). Acetate production from hydrogen and $\left({ }^{13} \mathrm{C}\right)$ carbon dioxide by the microflora of human faeces. Applied and Environmental Microbiology 54, $2723-2727$.

Liu, Y. F., Fadden, K., Latymer, E., Low, A. G. \& Hill, M. J. (1985). The use of the cannulated pig to study the effect of dietary fibre supplements on the bacterial flora of the porcine hindgut. In Digestive Physiology of the Pig, Report no. 580, pp. 300-303 [A. Just, H. Jorgensen and J. A. Fernandez, editors]. Copenhagen: National Institute of Animal Science.

Longland, A. C., Close, W. H. \& Low, A. C. (1989). The role of the large intestine in influencing the use of fibrous feeds by pigs. In Energy Metabolism of Farm Animals, pp. 111-114. Wageningen: Pudoc.

Longland, A. C. \& Low, A. G. (1989). Digestion of diets containing molassed or plain sugar-beet pulp by growing pigs. Animal Feed Science and Technology 23, 67-78.

Longstaff, M., Knox, A. \& McNab, J. M. (1988). Digestibility of pentose sugars and uronic acids and their effect on chick weight gain and caecal size. British Poultry Science 29, 379-393.

Longstaff, M. \& McNab, J. M. (1987). Digestion of starch and fibre carbohydrates in peas by adult cockerels. British Poultry Science 28, 261-285.

Mathers, J. C., Fernandez, F., Hill, M. J., McCarthy, P. T., Shearer, M. J. \& Oxley, A. (1990). Dietary modification of potential vitamin $\mathrm{K}$ supply from enteric bacterial menaquinones in rats. British Journal of Nutrition 63, 639-652.

Mathers, J. C. \& Miller, E. L. (1981). Quantitative studies of food protein degradation and the energetic efficiency of microbial protein synthesis in the rumen of sheep given chopped lucerne and rolled barley. British Journal of Nutrition 45, 587-604.

Metcalf, A. M., Phillips, S. F., Zinsmeister, A. R., MacCarty, R. L., Beart, R. W. \& Wolff, B. G. (1987). Simplified assessment of segmental colonic transit. Gastroenterology 92, 40-47.

Millard, P. \& Chesson, A. (1984). Modifications to swede (Brassica napus L.) anterior to the terminal ileum of pigs: some implications for the analysis of dietary fibre. British Journal of Nutrition 52, 583-594.

Nyman, M., Asp, N.-G., Cummings, J. \& Wiggins, H. (1986). Fermentation of dietary fibre in the intestinal tract: comparison between man and rat. British Journal of Nutrition 55, 487-496.

Petterson, D. \& Åman, P. (1989). Enzyme supplementation of a poultry diet containing rye and wheat. British Journal of Nutrition 62, 139-149.

Prins, R. A. \& Lankhorst, A. (1977). Synthesis of acetate from $\mathrm{CO}_{2}$ in the cecum of some rodents. FEMS Microbiological Letters 1, 255-258.

Sandberg, A.-S., Andersson, H., Hallgren, B., Hasselblad, K., Isaksson, B. \& Hultén, L. (1981). Experimental model for in vivo determination of dietary fibre and its effect on the absorption of nutrients in the small intestine. British Journal of Nutrition 45, 283-294.

Sandberg, A.-S., Andersson, H., Kivistö, B. \& Sandström, B. (1986). Extrusion cooking of a high-fibre cereal product. 1. Effects on digestibility and absorption of protein, fat, starch, dietary fibre and phytate in the small intestine. British Journal of Nutrition 55, 245-254.

Stephen, A. M. \& Cummings, J. H. (1980). The microbial contribution to human faecal mass. Journal of Medical Microbiology 13, 45-56.

Stephen, A. M., Wiggins, H. S. \& Cummings, J. H. (1987). Effects of changing transit time on colonic microbial metabolism in man. Gut 28, 601-609.

Van Soest, P. J. (1984). Some physical characteristics of dietary fibres and their influence on the microbial ecology of the human colon. Proceedings of the Nutrition Society 43, 25-33.

Van Soest, P. J., Jeraci, J., Foose, T., Wrick, K. \& Ehle, F. (1983). Comparative fermentation of fibre in man and other animals. In Fibre in Human and Animal Nutrition, pp. 75-80 [G. Wallace and L. Bell, editors]. Wellington: The Royal Society of New Zealand.

Wolin, M. J. \& Miller, T. L. (1983). Carbohydrate fermentation. In Human Intestinal Microflora in Health and Disease, pp. 147-165 [D. J. Hentges, editor]. New York: Academic Press. 